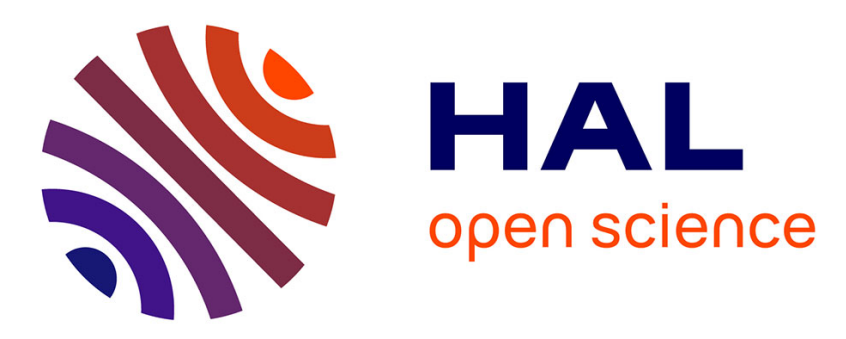

\title{
Rare earth elements in French stream waters -revisiting the geochemical continental cycle using FOREGS dataset
}

Romain Armand, Claudia Cherubini, Johann Tuduri, Nicola Pastore, Olivier Pourret

\section{To cite this version:}

Romain Armand, Claudia Cherubini, Johann Tuduri, Nicola Pastore, Olivier Pourret. Rare earth elements in French stream waters -revisiting the geochemical continental cycle using FOREGS dataset. Journal of Geochemical Exploration, 2015， 10.1016/j.gexplo.2015.06.006 hal-02136350

\section{HAL Id: hal-02136350 https://hal.science/hal-02136350}

Submitted on 22 May 2019

HAL is a multi-disciplinary open access archive for the deposit and dissemination of scientific research documents, whether they are published or not. The documents may come from teaching and research institutions in France or abroad, or from public or private research centers.
L'archive ouverte pluridisciplinaire HAL, est destinée au dépôt et à la diffusion de documents scientifiques de niveau recherche, publiés ou non, émanant des établissements d'enseignement et de recherche français ou étrangers, des laboratoires publics ou privés. 


\section{Rare earth elements in French stream waters - revisiting the}

\section{2 geochemical continental cycle using FOREGS dataset}

3

4 Romain Armand ${ }^{1}$, Claudia Cherubini ${ }^{1}$, Johann Tuduri ${ }^{2}$, Nicola Pastore ${ }^{3}$, Olivier Pourret ${ }^{1 *}$

5

$6{ }^{1}$ HydrISE, Institut Polytechnique LaSalle Beauvais, 60026 Beauvais cedex, France

$7 \quad{ }^{2}$ BRGM, ENAG (BRGM School), 3 avenue Claude Guillemin, 45100 Orléans, France

$8 \quad{ }^{3}$ Polytechnical University of Bari, Bari, Italy

9

10 *Corresponding author. Tel.: +33 3440689 79; fax: +33 344062526 ; e-mail address:

11 olivier.pourret@lasalle-beauvais.fr 


\section{Abstract}

The geochemical behavior of rare earth elements (REE) has been investigated mainly in geological systems where these elements represent the best proxies of processes involving the occurrence of an interface between different media. This behavior is assessed according to REE concentrations recorded along the REE series normalized with respect to upper continental crust. In this study based on a field approach, the geochemical behavior of REE was investigated in French stream waters. This study is based on FOREGS (Forum of European Geological Surveys) Geochemical dataset that consists on a sampling at regular mesh on all Europe. In France, 119 stream water samples were extracted in drainage basins $<100 \mathrm{~km}^{2}$. The aim of the study is that of describing the spatial variation of REE and finding the hydro-topo-geochemical factors that affect their distribution by means of a Multivariate Factorial Kriging.

On the basis of their atomic number and of the results of a preliminary Principal Component Analysis three REE have been selected (La, Eu and Lu) and five physicochemical properties $(\mathrm{pH}$, organic carbon, carbonates, $\mathrm{Fe}, \mathrm{Mn})$. A cokriging has been applied that shows a similar spatial organization of REE: higher values are especially observed in the Aquitaine basin. In order to investigate more deeply on the different sources of variation acting in the study area, a factorial cokriging is applied. The first 2 regionalized factors have been estimated to give a synthetic description of the studied process at the different selected spatial scales. At higher spatial scales $(250 \mathrm{~km})$ environmental parameters like $\mathrm{Fe}$, carbonates, $\mathrm{pH}$, supposed to be ascribed to the rock's nature or to other geological larger scale processes (i.e., hydrographic network and topography), have shown to affect REE distribution. At short range, only Eu and Mn weigh more, which are ascribed to the process of liberation of Mn oxides in rivers that also release the REE sorbed onto these oxides.

Keywords lanthanide, river water, organic matter, Fe and Mn oxides 


\section{Introduction}

Rare earth elements (REE) represent a group of fifteen elements, which share common physiochemical properties and therefore often occur together (McLennan and Taylor, 2012). Over the past fifteen years, REE became of critical importance to many green-technology products but also for medical applications, and therefore are of great economic interest (e.g., (Tepe et al., 2014; Guyonnet et al., 2015). In this context as highlighted by Kulaks1z and Bau (2013), the continuous development of new technologies and new substances has led to strongly increased release of REE into natural waters, although their toxicological effects and the potential implications for the ecosystem are often not fully understood. But in aquatic systems, REE concentrations are low compared to their concentrations in rocks with regards to their slight solubility (e.g., Noack et al., 2014). Therefore, it appears important first, to assess and to fully understand the occurrence and fate of aqueous REE in an environment where REE release from the anthroposphere may be considered as negligible.

In aquatic systems, solution and interface chemistry appears to be the major factor controlling the REE concentration (e.g., Elderfield et al., 1990; Sholkovitz, 1995). Rare earth elements can form strong complexes with a number of different ligands. For convenience, REE concentrations of continental waters are usually normalized to Upper Continental Crust (UCC; McLennan, 2001), which produces smooth REE $_{U C C}$ distribution patterns. The REE patterns result from the combination of several processes able to induce their fractionation. These processes are themselves controlled by several physicochemical mechanisms and parameters. Three processes can be distinguished: (i) precipitation/dissolution, (ii) sorption onto colloids and particles, and (iii) complexation in solution with organic and inorganic ligands. The resulting REE pattern therefore corresponds to the REE pattern for mineral sources that are modified by the sorption/complexation with ligands, colloids and particles. This results in a wide range of diverse REE patterns, which can be characterized by a 
depletion or enrichment degree of light REE (LREE) relative to heavy REE (HREE) or by whether or not anomalies occur. Indeed, individual REE may show anomalous behavior in natural waters: redox-sensitive $\mathrm{Ce}$ and Eu may show anomalies that may be used as redoxand/or temperature-proxies (e.g., Bau, 1991; De Baar et al., 1988), and La, Gd and Lu may show small anomalies due to subtle differences between the stabilities of REE complexes (Bau, 1999; Byrne and Kim, 1990). In addition to these natural anomalies, anthropogenic anomalies of $\mathrm{Gd}$ and, recently, $\mathrm{La}$ and $\mathrm{Sm}$ have been reported from natural waters (e.g., Kulaksız and Bau, 2013), and references therein).

To better understand the occurrence of aqueous metals and especially REE, the FOREGS (Forum of European Geological Surveys) aims at providing a basis for formulating policies and legislation concerning the management of harmful elements and to define their corresponding safety levels (Salminen et al., 2005). A first attempt was performed in Italy, Sweden and Europe by Imrie et al. (2008); Lado et al. (2008); Petrosino et al. (2013); Sadeghi et al. (2013). These studies mostly focus on topsoil dataset and investigate the main factors explaining REE variation in the soil solution; however, the FOREGS database contains descriptions of other environmental media (stream and floodplain sediments, and stream water). The database has been processed by Imrie et al. (2008); Lado et al. (2008), Petrosino et al. (2013) and Sadeghi et al. (2013) by means of multivariate approaches to interpolate all variables, metals or REE concentrations. They used factorial kriging for Imrie et al. (2008), regression kriging for Lado et al. (2008) and inverse distance weighted interpolation and principal component analysis for Sadeghi et al. (2013). The results associate spatial distribution of elements with different factors operating at several scales. For example, Imrie et al (2008) highlight four factors and amongst them (i) a short scale (72 km): concentrations may be explained by parent material geology, land use and organic matter content; (ii) a 
medium scale $(296 \mathrm{~km})$ : concentrations may be explained by major structural division of European continent and the distribution of calcareous rocks. Petrosino et al. (2013) show that in Italy and Sweden, REE concentration in all sampling medias are related to the geological context. In the particular case of stream water, they found that Swedish waters are more concentrated in REE than Italian waters. These authors relate high REE concentrations to water acidity (linked to vegetation and felsic rocks). Whereas, in Italy, $\mathrm{pH}$ is higher and the watershed are mostly composed of calcareous rocks which mostly explain the lower REE contents as already highlighted by Johannesson and Burdige (2007) or Deberdt et al. (2002). related to geology, topography, climate, and vegetation (e.g., Andersson and Nyberg, 2009; Gaillardet et al., 2014); the aim of this study is to further investigate the FOREGS dataset focusing on France. A special attention will be given to REE patterns spatial distribution. For such needs, the FOREGS stream dataset was processed by means of geostatistical methods, especially by factor kriging analysis. These approaches have three steps described as follows: (i) modeling the coregionalization of the set of variables, (ii) analyzing the correlation structure between the variables by applying principal component analysis; (iii) cokriging specific factors at each characteristic scale. The 14 REE concentrations available in the dataset were all used as inputs, as well as some physicochemical properties: $\mathrm{pH}$, carbonate alkalinity, Fe, Mn and organic carbon. The obtained maps allow visualizing the factors which integrate REE spatial variability. This variability is discussed with some landscape factors, especially topography and upstream/downstream location. 


\section{Materials and methods}

\subsection{The study area}

The geology of France results of a succession of events related to assembly and disruption of Gondwana and Pangea megacontinents and climate changes. Geographically, France has acquired a rugged topography giving it a wide range of outcropping terranes spanning from Proterozoic to Cenozoic (Figure 1). France can be divided into four geological terranes. (i) France is mostly covered by Mesozoic and Cenozoic deposits which correspond to intracratonic sedimentary basins like Paris Basin or Aquitaine Basin (Biteau et al., 2006; Guillocheau et al., 2000). These extensive areas have been scarcely deformed and are characterized by small dip values and concentric rock deposits. The tabular structure involves typical landscapes like alluvial plains, plateau and hills. In addition to intracratonic genesis, other basins correspond to grabens formed during Alps orogeny (Rhein and Limagnes graben). These units are generally depressions filled with Cenozoic sediments. (ii) These Mesozoic and Cenozoic sedimentary units lay on a basement composed of Paleozoic and Proterozoic rocks (Ballèvre et al., 2009; Faure et al., 2009). The basement is widely metamorphic and magmatic and is surrounded by discordant Mesozoic sedimentary cover. It constitutes the essential part of eroded mountain ranges like Vosges, Armorican Massif or French Massif Central erected during Cadomian and Variscan orogeny (Ballèvre et al., 2009; Faure et al., 2009). These reliefs have been strongly flattened by erosion, except to Vosges and French Massif Central which have been surrected again during Alps orogeny (Faure et al., 2009). (iii) Alps and Pyrenees are recent mountain ranges still erecting since Upper Cretaceous (Choukroune, 1992; Lagabrielle and Lemoine, 1997; Rosenbaum and Lister, 2005; Vissers and Meijer, 2012). These ranges form a complex association between mesocenoizoic rocks which have been heavily deformed due to fault and folding action and 
basement units. The resulting landscape is high mountains (Valla et al., 2011). (iv) Recent volcanic ranges are located massively in the Massif Central (Michon and Merle, 2001). These

\subsection{The FOREGS dataset}

The FOREGS program uses standardized field, analytical and quality control procedures to produce reliable reproducible geochemical data over Europe (Salminen et al., 1998).Therefore, the FOREGS initiated a program to construct a geochemical database with the aim of compiling the first geochemical atlas of Europe (Fedele et al., 2008). The field manual by Salminen et al. (1998) is the basis for a decade-long project, involving geochemists from 26 countries, which led to the publication of the Geochemical Atlas of Europe (De Vos and Tarvainen, 2006; Salminen et al., 2005). As a result, a large geochemical database is now available free for public use $e^{1}$ (De Vos and Tarvainen, 2006; Salminen et al., 2005).

\subsubsection{Sampling strategy}

(1)

The FOREGS sampling grid (Salminen et al., 1998; Tarvainen et al., 2005) was based on the Global Terrestrial Network (GTN) grid composed of 160 × $160 \mathrm{~km}$ cells and developed for the purpose of Global Geochemical Baselines Mapping (Darnley et al., 1995). For each cell, five randomly generated sites were selected, according to the following scheme:

- Point number 1 is located in the NE quadrant of the GTN grid cell;

- Point number 2 in the NW quadrant;

\footnotetext{
${ }^{1}$ http://weppi.gtk.fi/publ/foregsatlas/index.php
} 
- Point number 3 in the SW quadrant;

- $\quad$ Point number 4 in the SE quadrant;

- Point number 5 is randomly located in anyone of the four quadrants of the GTN grid cell.

As a result, France was divided into 25 cells and 119 sample sites were determined. Based on former randomly generated points, five nearest small drainage basins of $<100 \mathrm{~km}^{2}$ were selected. For each cell, a larger drainage basin (area 1,000-6,000 $\mathrm{km}^{2}$ ), to which the small drainage basin is connected, was selected. The floodplain sediment samples were collected either from a suitable point near its outlet with the sea or the confluence point with another major river system. In this study, French stream water samples were selected. The dataset consists of 119 sampling sites (one sample per site). However, 4 sites located in Corsica were removed of the dataset to obtain a homogeneous spatial distribution. Samples were collected during two periods of the winter: from November 1998 to December 1998; and from March 1999 to October 1999. Sampling during rainy periods and flood events was avoided. According to FOREGS stream water sampling procedure, running stream water was collected from the small, second order, drainage basins $\left(<100 \mathrm{~km}^{2}\right)$. Physico-chemical parameters $(\mathrm{pH}$, temperature and electrical conductivity) were measured at the site while several stream water samples were collected. ICP-MS analyses were performed on a $100 \mathrm{~mL}$ sample filtered to $0.45 \mu \mathrm{m}$ (Salminen et al. 1998).

\subsubsection{Chemical analyses and quality controls}

As described in Sandström et al. (2005): stream water samples were acidified to $1 \%$ v/v with nitric acid and stored at less than $8^{\circ} \mathrm{C}$. The samples were analyzed by both inductively coupled plasma quadrupole mass spectrometry (ICP-QMS) and inductively coupled plasma atomic emission spectrometry (ICP-AES), using Perkin Elmer Sciex ELAN 
5000A and Spectro Flame M instruments respectively, in accordance with the German norms DIN 38406-29 (ICP-MS) and DIN 38406-22 (ICP-AES). Analyses were performed by BGR (Bundesanstalt für Geowissenschaften und Rohstoffe, Hannover, Germany). The primary chemicals used to prepare the calibration and quality control standards and reagents were of analytical reagent grade. Multi-element standard solutions for calibration were prepared from Claritas SPEX/Certiprep stock solutions. International certified reference materials (NIST 1640, NIST 1643d and SLSR-4) were included in every batch of 20 samples. Indium was used as an internal standard. The accuracy of the methods for all determinants is better than $\pm 10 \%$, the bias is within $\pm 3 \%$, and the repeatability at the $95 \%$ confidence interval is better than $5 \%$ at concentrations an order of magnitude above the limit of quantification. Limits of quantification for all cations and trace metals are given in Sandström et al. (2005).

\subsection{Geographic information system and multivariate geostatistical approach.}

Geographic information system (GIS) analysis was performed with ArcGis 10 software. Distance between sample site and outlet was calculated using the BD Carthage (Sandre Eau France) dataset which is the French official dataset about hydrographic network. Geological context of sampling sites was obtained by GIS intersection with $1 / 1,000,000$ geological units (BRGM One Geology).

Concentrations of $14 \mathrm{REE}$ and physicochemical properties $\left(\mathrm{pH}\right.$, carbonate alkalinity as $\mathrm{HCO}_{3}$, Fe, Mn and organic carbon) were used as inputs for the geostatistical method. Descriptive statistics (mean, standard deviation sd, median med, and median absolute deviation MAD) were performed on all variables and normality of data and homogeneity of variances were verified. As data behave following a not normal distribution, non-parametric Kruskal-Wallis tests were performed to quantify differences in variables within geological contexts. 
The multivariate spatial data were analyzed by cokriging and Factor Kriging Analysis (FKA)

212 which is a geostatistical method developed by Matheron (1982). The FKA consists of

213 decomposing the set of original second-order random stationary variables $\left\{Z_{i}(x), i=1, \ldots, n ;\right\}$

214 into a set of reciprocally orthogonal regionalized factors $\left\{\mathrm{Y}^{\mathrm{u}}{ }_{\mathrm{v}}(\mathrm{x}), \mathrm{v}=1, \ldots, \mathrm{n} ; \mathrm{u}=1, \ldots, \mathrm{N}_{\mathrm{s}}\right\}$

215 where $N_{S}$ is the number of spatial scales, through transformation coefficients $a^{u}{ }_{\text {iv }}$ (loadings

216 components score) combining the spatial with the multivariate decomposition:

$217 \quad Z_{i}(x)=\sum_{u=1}^{N_{S}} \sum_{v=1}^{n} a_{i v}^{u} Y_{v}^{u}(x)$

218 The three basic steps of FKA are the following:

219 (i) Modeling the coregionalization of the set of variables, using the so called Linear Model of

220 Coregionalization (LMC);

221 (ii) Analyzing the correlation structure between the variables, by applying Principal

222 Component Analysis (PCA) at each spatial scale;

223 (iii) Cokriging specific factors at each characteristic scale and mapping them.

\subsubsection{Linear Model of Coregionalization}

The LMC, developed by Journel and Huijbregts (1978), considers all the studied variables as the result of the same independent physical processes, acting at different spatial scales $u$. The $n(n+1) / 2$ simple and cross variograms of the $\mathrm{p}$ variables are modeled by a linear

$231 \quad \Gamma(h)=\sum_{u=1}^{N_{S}} B^{u} g^{u}(h)$ 
where $\Gamma(h)=\left[\gamma_{i j}(h)\right]$ is a symmetric matrix of order $n \times n$, whose diagonal and non-diagonal elements represent simple and cross variograms for lag $h ; B^{u}=\left[b^{u}{ }_{i j}\right.$ is called coregionalization matrix and it is a symmetric semi-definite matrix of order $n \times n$ with real elements $b_{i j}^{u}$ at a specific spatial scale $u$. The model is authorized if the functions $g^{u}(h)$ are authorized variogram models. In the LMC the spatial behavior of the variables is supposed resulting from superimposition of different independent processes working at different spatial scales. These processes may affect the behavior of experimental semi-variograms, which can then be modeled by a set of functions $\mathrm{g}^{\mathrm{u}}(\mathrm{h})$. The choice of number and characteristics (model, sill, range) of the functions $\mathrm{g}^{\mathrm{u}}(\mathrm{h})$ is quite delicate and can be made easier by a good experience of the studied phenomena (Chilès and Guillen, 1984). Fitting of LMC is performed by weighed least-squares approximation under the constraint of positive semidefiniteness of the $\mathrm{B}^{\mathrm{u}}$, using the iterative procedures developed by Goulard (1989). The best model was chosen, as suggested by Goulard and Voltz (1992), by comparing the goodness of fit for several combinations of functions of $g^{\mathrm{u}}(\mathrm{h})$ with different ranges in terms of the weighted sum of squares.

\subsubsection{Regionalized Principal Component Analysis}

Regionalized Principal Component Analysis consists of decomposing each coregionalization matrix $\boldsymbol{B}^{u}$ into two other diagonal matrices: the matrix of eigenvectors and the diagonal matrix of eigenvalues for each spatial scale $\mathrm{u}$ through the matrix $\boldsymbol{A}^{u}$ of order $\mathrm{n} \mathrm{x}$ $\mathrm{n}$ of the transformation coefficients $a^{u}{ }_{i v}$ (Wackernagel, 2003). The transformation coefficients $a^{u}{ }_{i v}$ in the matrix $\boldsymbol{A}^{u}$ correspond to the covariances between the original variables $\mathrm{Z}_{\mathrm{i}}(\mathrm{x})$ and the regionalized factors $\mathrm{Y}_{\mathrm{v}}^{\mathrm{u}}(\mathrm{x})$. 


\subsubsection{Mapping multivariate spatial information}

The behavior and relationships among variables at different spatial scales can be displayed by interpolating the regionalized factors $\mathrm{Y}_{\mathrm{v}}^{\mathrm{u}}(\mathrm{x})$ using cokriging and mapping them (Castrignanò et al., 2007, 2000). The cokriging system in FKA has been widely described by Wackernagel (2003).

\section{Results}

3.1 Relationships between stream data and geology.

Table 1 shows the descriptive statistics of all variables between the geological contexts. The majority of the 115 samples is located in sedimentary areas $(n=85)$, among them 40 are carbonate derived rocks, 9 chalks, 12 clays and 24 sand and sandstoness. The others are located in metamorphic $(n=18)$, acidic plutonic $(n=8)$ and acidic volcanic $(n=3)$ contexts. Most of physicochemical properties and selected REE show significant differences between the geological contexts: $\mathrm{pH}$, carbonate alkalinity, $\mathrm{Fe}, \mathrm{La}$ and $\mathrm{Lu}$. This suggests the influence of surrounding rocks geology on water chemistry. Water samples taken from sedimentary areas are characterized by higher carbonate alkalinity concentrations (from $69 \mathrm{mg} / \mathrm{L}$ to 134 $\mathrm{mg} / \mathrm{L}$ ) and alkaline $\mathrm{pH}$ value (from 7.68 to 8.02 ) which is explained by carbonates presence in sedimentary rocks. Higher Fe concentrations $(176 \mathrm{mg} / \mathrm{L}$ and $224 \mathrm{mg} / \mathrm{L}$ respectively) are observed in both acidic plutonic and metamorphic areas. Regarding $\mathrm{La}, \mathrm{Eu}$ and $\mathrm{Lu}$ concentrations, higher concentrations are observed in samples taken from metamorphic and concentrations are derived from carbonate rocks $(0.0280 \mu \mathrm{g} / \mathrm{L}$ for $\mathrm{La})$. This is consistent with 
REE sources essentially located in metamorphic and magmatic rocks (from 50 to $100 \mathrm{mg} / \mathrm{kg}$ for La; Henderson, 1984; McLennan, 1989) whereas REE content in carbonates is low (10 $\mathrm{mg} / \mathrm{kg}$ for La; Turekian and Wedepohl, 1961).

\subsection{Principal Component Analysis}

The classical statistical technique based on the PCA has been applied in order to investigate on the behavior of the variables in relation to the principal components. Since geochemical data are compositional, every data set should be opened, prior to its statistical treatment, using a preferred method from a variety of suggested methods (Sadeghi et al., 2014). In this study, statistical PCA has been performed using the ln-transformed data sets (Pawlowsky-Glahn and Buccianti, 2011). The generated results are given in Table 2. The PCA, performed in this study, using ln-transformed data has successfully opened the data. Using PCA, two principal components were extracted that cumulatively explained $90.6 \%$ of the total data variability and with an eigenvalue greater than 1 (Table 2). The other components had an eigenvalue less than 1 and were not used. Generally, the first components account for most of the variability contained in the data set (Johnson and Wichern, 2002). In the case study the first two principal components were used in the analysis, mainly due to the presence of such correlations with the real properties, as shown in the circle of correlations presented in Figure 2. The circle of correlation shows the proximity of the variables inside a unit circle and is useful to evaluate the affinity and the antagonism between the variables. Statement can easily be made about variables which are located near the circumference of the unit circle. In our case the first component is highly correlated with all REE and also Fe, while the $\mathrm{Mn}, \mathrm{OC}, \mathrm{pH}$, carbonate alkalinity are located a little further away from the circumference and appear to have a different behavior. They all are correlated negatively with the F2. From an analysis of 
the circle it is possible to see that all the HREE are positioned in the upper part and all the LREE in the lower part of the semi circumference. Europium shows a slightly different behavior as it is more detached from the circumference, and is close to Fe. From the PCA it appears that the first regionalized factor explains the behavior of the REE and separates them from the other elements. No substantial additional information is provided by the F2.

\subsection{Coregionalization analysis}

The variables are highly shifted from the Gaussian distribution so they were normalized and standardized to mean 0 and variance 1 . On the basis of the results of principal component analysis, a choice has been made between the 19 variables. The chosen parameters are $\mathrm{Fe}, \mathrm{Mn}$, carbonate alkalinity, organic carbon and $\mathrm{pH}$ for the physicochemical properties together with $\mathrm{La}, \mathrm{Lu}$ and Eu for the REE. La is representative of LREE, Lu of HREE and Eu has been chosen because of his peculiar behavior (McLennan and Taylor, 2012). Using GAMV of GSLIB library (Deutsch and Journel, 1992) the experimental variograms and cross-variograms of the 3 REEs and $\mathrm{Fe}, \mathrm{Mn}$, carbonate alkalinity, organic carbon and $\mathrm{pH}$ has been obtained with lag separation distance equal to $20 \mathrm{~km}$. No relevant anisotropy was observed in the variogram maps and the experimental variograms looked upper bounded. The linear coregionalization model has been obtained using the LCMFIT2 program (PardoIguzquiza and Dowd, 2002) to fit the 36 experimental variograms. The LMC was fitted using two spatial structures: a spherical model with a range of $120 \mathrm{~km}$ and a spherical model with a range of $250 \mathrm{~km}$. The linear coregionalization models (direct and cross-variograms) (not shown) appear well spatially structured also due to the absence of the not-spatially correlated component (nugget effect). The spatial cross-correlation is shown in Table 3. The appropriateness of the LCM and the basic structures was evaluated with a cross-validation test by calculating the mean error and the variance of standardized error, which were quite close 
to 0 (varying between -0.033 and 0.0145 ) and 1 (varying between 0.9 and 1.2 ), respectively. These results mean that the estimates were unbiased and the estimation variance reproduced the experimental variance accurately.

\subsection{Factorial kriging}

Using FACTOR2d program (Pardo-Iguzquiza and Dowd, 2002) a factorial cokriging is used to estimate the first 2 regionalized individual factors that, at the cost of an acceptable loss of information, have given a synthetic description of the process in study at the different selected spatial scales. As no nugget effect has been modeled, the short-range and long-range components of the first two regionalized factors were selected. The long range component $(250 \mathrm{~km})$ of the first two factors explains most variance $(80.3 \%$ and $17.0 \%$, respectively) while the short range component explains just the $50.0 \%$ and $20.2 \%$ for $\mathrm{F} 1$ and $\mathrm{F} 2$ respectively, which is less representative. The long range component of the first factor shows to be the most explicative as it is correlated with most of the elements positively, such as $\mathrm{Fe}$ (0.796), $\mathrm{La}(0.814), \mathrm{Lu}(0.603)$, organic carbon (0.639) and negatively with $\mathrm{HCO}_{3}{ }^{-}(-0.607)$, pH (-0.648) (Table 4). The F1 at long range synthesizes the long range variability of the whole elements with a localized higher value zone in the central and south-eastern part. The short range component $(120 \mathrm{~km})$ of the first factor is mostly correlated with $\mathrm{Eu}(0.773)$ and Mn (0.687). Europium shows a different behavior being mostly explained by the F1 at the short spatial scale. However, in order to get more precise information about its structure, additional data should be collected to infer the variability at a smaller spatial scale. As far as the F2, it does not show to be correlated at all with the REE but it is correlated more with the physico-chemical parameters, such as with the $\mathrm{pH}$ at small spatial scale $(0.580)$. 


\subsection{Cokriging}

Cokriging was applied to the transformed data to obtain the estimates which were then back-transformed to express them in the original variables. The spatial maps of the eleven variables were obtained by cokriging on a $10 \mathrm{~km} \times 10 \mathrm{~km}$ square grid. Figures 3,4 and 5 represent, respectively, the first regionalized factor at short range and at long range, the 3 selected REEs and the 5 physicochemical properties. From an analysis of the cokriged maps it is possible to see that REE exhibit all similar spatial distributions, with extended higher values in the south-western part, in correspondence with the depression of Aquitaine basin (low area surrounded by higher land and usually characterized by interior drainage). Other zones of localized higher value correspond with the Alpine valley corridors of the Rhône, the hydrographic network of the Seine basin, hydrographic network of the Loire with its effluents. Another zone of higher values is localized in correspondence of the Oise basin, in the Paris basin. The anisotropy (SW-NE for the southern part and NW-SE for the northern part of France) showed in the maps of REE is coherent with the direction of propagation of rivers except for the Aquitaine basin where the high concentrations are due to the interior drainage of the low area. Organic carbon and Mn show similar behavior having higher zone values concentrated in the same areas of the REE, while carbonate alkalinity and $\mathrm{pH}$, show a totally contrasting behavior with the rest of the variables (being negatively correlated).

\section{Discussion}

\subsection{Assessment of factor kriging analysis}

The long range component of the first factor shows to be the most explicative $(80.3 \%$ of the variance) as it synthesizes the long range variability of most of the elements ( $\mathrm{Fe}, \mathrm{La}, \mathrm{Lu}$, 
organic carbon, carbonate alkalinity and $\mathrm{pH}$ ) with a localized higher value zone in the central and south-eastern part. Therefore at high spatial scales environmental parameters like Fe, carbonates, $\mathrm{pH}$, are supposed be ascribed to the rock's nature or to other larger scale processes (i.e., river network). The structure of the hydrographic network is determined by a complex of physicogeographic conditions especially by climate, by the topography, and by the geological structure of the locality. Indeed, hydrographic network and topography have shown to affect REE distribution (e.g., Kohler et al., 2014). The short range component of the first factor explains just the $50.0 \%$ of the variance and is mostly correlated with Eu (0.773) and Mn (0.687). So at short range, just the Eu and Mn weigh more, which are ascribed to the process of $\mathrm{Mn}$ oxides release in rivers simultaneously with REE sorbed on these oxides (Koeppenkastrop and De Carlo, 1993). Indeed, Mn oxides behave like Fe oxides, and as evidenced by Steinmann and Stille (2008) saturation index of goethite decrease with transport and resulting REE fractionation in the stream water.

To sum up, only the first regionalized factor corresponding to long range is representative of the conjoint variability of the elements in study. The short range variability has not proved to explain the behavior of the variables satisfactorily. The sampling scale adopted is too wide and can give sufficient information for a correlation scale of hundreds of kilometers. To be able to infer the variation at a smaller scale, further sampling on a finer spatial scale would be needed.

\subsection{Rare earth elements as tracer of hydrological transfer}

Research results from past twenty years clearly show an influence of topography on stream water chemistry. Moreover several authors have proved that topography was the attribute that had the major influence on stream water chemistry (Andersson and Nyberg, 
2009; Ogawa et al., 2006). The influence of topography is important because it controls the water subsurface contact time (Beven and Kirkby, 1979; Dillon and Molot, 1997; McGuire et al., 2005; Wolock et al., 1990). Topography is of great significance in hydrology, affecting soil water content, flowpaths and residence times (Nyberg, 1995), and subsequently the chemical composition of surface waters (Beven, 1986; Wolock et al., 1989). Such a feature was thus tested on REE as previously shown by Köhler et al. (2014): in boreal catchments REE export is mostly strongly controlled by landscape type. In continental systems, percolation of rain water through the rocks will result in low-temperature chemical weathering reactions that will slowly break down the primary minerals, possibly resulting in mobility of the REE. The chemistry of groundwater is clearly very dependent on the physicochemical environments through which it has passed.

A focus on the Garonne and Dordogne systems, in correspondence to the Aquitaine basin characterized by higher values and anisotropy, emphasized this feature. Indeed, both river systems originate in Massif Central, where low-temperature chemical weathering of acidic magmatic rocks occurs. Moreover, topography is escarped and results in low residence time. It is highlighted on figure 6, where REE patterns of considered samples depicted low REE concentration and negative cerium anomaly. Positive europium anomaly can be interpreted as a result of water rock interaction with feldspar from bedrocks (i.e., basalts; Steinmann and Stille, 2008). Both river systems then encountered the Aquitaine basin, with a more flat topography with higher residence time. It results in higher REE concentrations (figure 6), with middle REE enriched patterns, corresponding to an organic sedimentary input. Overall, spatial variability results in REE and organic carbon concentrations increase and a $\mathrm{pH}$ decrease (figure 7).

Wetlands would play a key role in the regulation of REE concentrations in the environment as earlier proposed (Davranche et al., 2014). Indeed REE are released in wetland 
bound to colloidal organic matter as also observed in watershed or rivers (Shiller, 2010;

431 Stolpe et al., 2013). Moreover, figure 7 shows the global control of dissolved REE

432

433 concentrations by $\mathrm{pH}$ as previously highlighted for Nd by Johannesson and Burdige (2007) or Deberdt et al. (2002). Indeed, pH can significantly influence the speciation and thus the behavior of the REE (Pourret et al., 2007; Tang and Johannesson, 2003). A decrease in pH will favor solution of the REE and thus their transport either as organic complexes or as free ions. In figure 8, cerium anomaly in these two river water systems are reported as a function of the distance to the outlet. Figure 8 shows that the two river water systems plot along a single trend reflecting the $\mathrm{Ce}$ anomaly amplitude gradual reduction as the distance to the outlet decreases. It must be noted that a few points $(n=3)$ have a different behavior from this trend and correspond to more organic water (associated to wetlands). As already proposed by Pourret et al. (2010) the likely reason for the Ce anomaly amplitude gradual reduction observed mainly relies on the fact that, in low permeability aquifers, water table generally reaches organic soil horizons in bottomland domains, thus allowing incorporation of large quantities of organic colloids in the aquifer bottomland part. This feature is not seen in the aquifer upland part where the water table always remains far below the upper, organic-rich soil horizons. Considering results from this study, it appears that the general feature of shallow groundwaters flowing into aquifers developed onto low permeability bedrock (Pourret et al., 2010) can be expanded to river water systems.

\section{Concluding remarks}

In order to further understand REE patterns spatial distribution, the FOREGS stream dataset was processed by means of geostatistical methods. The obtained maps allow visualizing the factors which integrate REE spatial variability. Cokriging shows a similar 


\section{Acknowledgments}

474 This work is funded by project ANR-11-ECOT-002 ASTER "Systematic analysis of Rare

475 Earths - Flows and Stocks".

spatial organization of REE: higher values are observed in the Aquitaine basin, more locally in the Alpine valley corridors of the Rhone, and along some tributaries of the Loire and the Seine. A factorial cokriging was applied to investigate more deeply the different sources of variation acting in the study area. The first 2 regionalized factors have been estimated to give a synthetic description of the studied process at the different selected spatial scales. At large spatial scales $(250 \mathrm{~km})$ environmental parameters like $\mathrm{Fe}$, carbonates, $\mathrm{pH}$, are supposed be ascribed to the rock's nature (plutonic, volcanic and metamorphic versus sedimendary) or to other larger scale processes, such as hydrographic network and topography have shown to affect REE distribution. The factor kriging analysis used in this study reveals the spatial patterns of REE in stream water. REE are positively correlated to $\mathrm{Fe}$ and $\mathrm{Mn}$ and negatively to carbonate alkalinity and $\mathrm{pH}$. At short range, only $\mathrm{Eu}$ and $\mathrm{Mn}$ weigh more, which are ascribed to the process of liberation of Mn oxides in rivers that also releases the REE sorbed onto these oxides. This variability is discussed with some landscape factors, especially topography and upstream/downstream location. However, the short range variability cannot be explained satisfactorily by the adopted sampling as the sampling scale is too wide and can give sufficient information for a correlation scale of hundreds of $\mathrm{km}$. To be able to infer the variation at a smaller scale, further sampling on a finer spatial scale would be needed.

\footnotetext{
Earths - Flows and Stocks".
} 
Andersson, J.-O., Nyberg, L., 2009. Using official map data on topography, wetlands and vegetation cover for prediction of stream water chemistry in boreal headwater catchments. Hydrology and Earth System Sciences 13, 537-549.

Ballèvre, M., Bosse, V., Ducassou, C., Pitra, P., 2009. Palaeozoic history of the Armorican Massif: Models for the tectonic evolution of the suture zones. Comptes Rendus Geoscience 341, 174201. doi:10.1016/j.crte.2008.11.009

Bau, M., 1991. Rare-earth element mobility during hydrothermal and metamorphic fluid-rock interaction and the significance of the oxidation state of europium. Chemical Geology 93, 219-230.

Bau, M., 1999. Scavenging of dissolved yttrium and rare earths by precipitating iron oxyhydroxide: Experimental evidence for Ce oxidation, Y-Ho fractionation, and lanthanide tetrad effect. Geochimica et Cosmochimica Acta 63, 67-77.

Beven, K.J., 1986. Hillslope runoff processes and flood frequency characteristics, in: Hillslope Processes. Allen and Unwin (ed.) Abrahams AD, pp. 187-202.

Beven, K.J., Kirkby, M.J., 1979. A physically based, variable contributing area model of basin hydrology. Hydrological Sciences Journal 24, 43-69.

Biteau, J.-J., Le Marrec, A., Le Vot, M., Masset, J.-M., 2006. The Aquitaine Basin. Petroleum Geoscience 12, 247-273.

Byrne, R.H., Kim, K.-H., 1990. Rare earth element scavenging in seawater. Geochimica et Cosmochimica Acta 54, 2645-2656.

Castrignanò, A., Cherubini, C., Giasi, C.I., Musci, F., Pastore, N., 2007. Multivariate Geostatistical and Natural Attenuation Model Approach for remediation of chlorinated compounds. WSEAS Transactions On Environment And Development 3, 90-98.

Castrignanò, A., Giugliarini, L., Risaliti, R., Martinelli, N., 2000. Study of spatial relationships among some soil physico-chemical properties of a field in central Italy using multivariate geostatistics. Geoderma 97, 39-60.

Chilès, J.P., Guillen, A., 1984. Variogrammes et krigeages pour la gravimétrie et le magnétisme. Sciences de la Terre, Série Informatique 20, 455-468.

Choukroune, P., 1992. Tectonic evolution of the Pyrenees. Annual Review of Earth and Planetary Sciences 20, 143.

Darnley, A., Björklund, A., Bølviken, B., Gustavsson, N., Koval, P.V., Plant, J.A., Steenfelt, A., Tauchid, M., Xie, X.J., 1995. A global geochemical database for environmental and resource management. Recommendations for international geochemical mapping. Final report of IGCP-project 259. UNESCO, Paris.

Davranche, M., Gruau, G., Dia, A., Marsac, R., Pédrot, M., Pourret, O., 2014. Biogeochemical Factors Affecting Rare Earth Element Distribution in Shallow Wetland Groundwater. Aquatic Geochemistry 1-19.

De Baar, H.J.W., German, C.R., Elderfield, H., van Gaans, P., 1988. Rare earth element distributions in anoxic waters of the Cariaco Trench. Geochimica et Cosmochimica Acta 52, 1203-1219. doi:doi:10.1016/0016-7037(88)90275-X

Deberdt, S., Viers, J., Dupré, B., 2002. New insights about the rare earth elements (REE) mobility in river waters. Bulletin de la Société Géologique de France 173, 147-160.

Deutsch, C.V., Journel, A.G., 1992. GSLIB: Geostatistical software library and user's guide. New York: Oxford University Press.

De Vos, W., Tarvainen, T., 2006. Geochemical Atlas of Europe. Part 2 - Interpretation of Geochemical Maps, Additional tables, Figures, Maps, and Related Publications. Geological Survey of Finland, Otamedia Oy, Espoo.

Dillon, P.J., Molot, L.A., 1997. Effect of landscape form on export of dissolved organic carbon, iron, and phosphorus from forested stream catchments. Water Resources Research 33, 2591-2600.

Elderfield, H., Upstill-Goddard, R., Sholkovitz, E.R., 1990. The rare earth elements in rivers, estuaries, and coastal seas and their significance to the composition of ocean waters. Geochimica et Cosmochimica Acta 54, 971-991. doi:doi:10.1016/0016-7037(90)90432-K 
Faure, M., Lardeaux, J.-M., Ledru, P., 2009. A review of the pre-Permian geology of the Variscan French Massif Central. Comptes Rendus Geoscience 341, 202-213. doi:http://dx.doi.org/10.1016/j.crte.2008.12.001

Fedele, L., Plant, J.A., De Vivo, B., Lima, A., 2008. The rare earth element distribution over Europe: geogenic and anthropogenic sources. Geochemistry: Exploration, Environment, Analysis 8, 318. doi:10.1144/1467-7873/07-150

Gaillardet, J., Viers, J., Dupré, B., 2014. 7.7 - Trace Elements in River Waters, in: Holland, H.D., Turekian, K.K. (Eds.), Treatise on Geochemistry (Second Edition). Elsevier, Oxford, pp. 195235.

Goulard, M., 1989. Inference in a coregionalization model, in: Geostatistics. Springer, pp. 397-408.

Goulard, M., Voltz, M., 1992. Linear coregionalization model: tools for estimation and choice of cross-variogram matrix. Mathematical Geology 24, 269-286.

Guillocheau, F., Robin, C., Allemand, P., Bourquin, S., Brault, N., Dromart, G., Friedenberg, R., Garcia, J.P., Gaulier, J.M., Gaumet, F., Grosdoy, B., Hanot, F., Le Strat, P., Mettraux, M., Nalpas, T., Prijac, C., Rigollet, C., Serrano, O., Grandjean, G., 2000. Meso-Cenozoic geodynamic evolution of the Paris Basin: 3D stratigraphic constraints. Geodinamica Acta 13, $189-245$.

Guyonnet, D., Planchon, M., Rollat, A., Escalon, V., Tuduri, J., Charles, N., Vaxelaire, S., Dubois, D. and Fargier, H. Material flow analysis applied to rare earth elements in Europe. Journal of Cleaner Production. doi:10.1016/i.jclepro.2015.04.123

Henderson, P., 1984. Rare earth element geochemistry. Elsevier, Amsterdam.

Imrie, C.E., Korre, A., Munoz-Melendez, G., Thornton, I., Durucan, S., 2008. Application of factorial kriging analysis to the FOREGS European topsoil geochemistry database. Science of The Total Environment 393, 96-110. doi:10.1016/j.scitotenv.2007.12.012

Johannesson, K.H., Burdige, D.J., 2007. Balancing the global oceanic neodymium budget: Evaluating the role of groundwater. Earth and Planetary Science Letters 253, 129-142. doi:doi:10.1016/j.eps1.2006.10.021

Johnson, R.A., Wichern, D.W., 2002. Applied Multivariate Analysis, 5th ed. Prentice Hall.

Journel, A.G., Huijbregts, C.J., 1978. Mining geostatistics. Academic press.

Koeppenkastrop, D., De Carlo, E.H., 1993. Uptake of rare earth elements from solution by metal oxides. Environmental Science \& Technology 27, 1796-1802. doi:doi:10.1021/es00046a006

Köhler, S.J., Lidman, F., Laudon, H., 2014. Landscape types and pH control organic matter mediated mobilization of $\mathrm{Al}, \mathrm{Fe}, \mathrm{U}$ and $\mathrm{La}$ in boreal catchments. Geochimica et Cosmochimica Acta 135, 190-202.

Kulaksız, S., Bau, M., 2013. Anthropogenic dissolved and colloid/nanoparticle-bound samarium, lanthanum and gadolinium in the Rhine River and the impending destruction of the natural rare earth element distribution in rivers. Earth and Planetary Science Letters 362, 43-50. doi:10.1016/j.epsl.2012.11.033

Lado, L.R., Hengl, T., Reuter, H.I., 2008. Heavy metals in European soils: A geostatistical analysis of the FOREGS Geochemical database. Geoderma 148, 189-199. doi:10.1016/j.geoderma.2008.09.020

Lagabrielle, Y., Lemoine, M., 1997. Alpine, Corsican and Apennine ophiolites: the slow-spreading ridge model. Comptes Rendus de 1'Académie des Sciences-Series IIA-Earth and Planetary Science 325, 909-920.

Matheron, G., 1982. Pour une analyse krigeante des données régionalisées (No. 732). Centre de Géostatistique, Fontainebleau.

McGuire, K.J., McDonnell, J.J., Weiler, M., Kendall, C., McGlynn, B.L., Welker, J.M., Seibert, J., 2005. The role of topography on catchment-scale water residence time. Water Resources Research 41.

McLennan, S.M., 1989. Rare earth element in sedimentary rocks: influence of provenance and sedimentary processes, in: Lipin B.R., Mc Kay G.A. (Eds.), Geochemistry and Mineralogy of Rare Earth Elements, pp. 169-200. 
McLennan, S.M., 2001. Relationships between the trace element composition of sedimentary rocks and upper continental crust. Geochemistry Geophysics Geosystems 2, 109. doi:10.1029/2000gc000109

McLennan, S.M., Taylor, S.R., 2012. Geology, Geochemistry and Natural Abundances of the Rare Earth Elements, in: Atwood, D.A. (Ed.), The Rare Earth Elements. Fundamentals and Applications. Wiley, Chichester, pp. 1-19.

Michon, L., Merle, O., 2001. The evolution of the Massif Central rift: Spatio-temporal distribution of the volcanism. Bulletin de la Société Géologique de France 172, 201-211.

Noack, C.W., Dzombak, D.A., Karamalidis, A.K., 2014. Rare earth element distributions and trends in natural waters with a focus on groundwater. Environmental Science \& Technology 48, 43174326. doi:10.1021/es4053895

Nyberg, L., 1995. Soil- and groundwater distribution, flowpaths and transit times in a small till catchment (PhD Thesis). Uppsala University, Sweden.

Ogawa, A., Shibata, H., Suzuki, K., Mitchell, M.J., Ikegami, Y., 2006. Relationship of topography to surface water chemistry with particular focus on nitrogen and organic carbon solutes within a forested watershed in Hokkaido, Japan. Hydrological processes 20, 251-265.

Pardo-Iguzquiza, E., Dowd, P.A., 2002. FACTOR2D: a computer program for factorial cokriging. Computers \& geosciences 28, 857-875.

Pawlowsky-Glahn, V. and Buccianti, A., 2011. Compositional Data Analysis: Theory and Applications. Wiley.

Petrosino, P., Sadeghi, M., Albanese, S., Andersson, M., Lima, A., De Vivo, B., 2013. REE contents in solid sample media and stream water from different geological contexts: Comparison between Italy and Sweden. Journal of Geochemical Exploration 133, 176-201. doi:10.1016/j.gexplo.2012.12.008

Pourret, O., Davranche, M., Gruau, G., Dia, A., 2007. Rare Earth Elements complexation with humic acid. Chemical Geology 243, 128-141. doi:doi:10.1016/j.chemgeo.2007.05.018

Pourret, O., Gruau, G., Dia, A., Davranche, M., Molénat, J., 2010. Colloidal control on the distribution of rare earth elements in shallow groundwaters. Aquatic Geochemistry 16, 31-59.

Rosenbaum, G., Lister, G.S., 2005. The Western Alps from the Jurassic to Oligocene: spatio-temporal constraints and evolutionary reconstructions. Earth-Science Reviews 69, 281-306.

Sadeghi, M., Morris, G.A., Carranza, E.J.M., Ladenberger, A., Andersson, M., 2013. Rare earth element distribution and mineralization in Sweden: An application of principal component analysis to FOREGS soil geochemistry. Journal of Geochemical Exploration 133, 160-175. doi:10.1016/j.gexplo.2012.10.015

Sadeghi, M., Billay, A. and Carranza, E.J.M. Analysis and mapping of soil geochemical anomalies: Implications for bedrock mapping and gold exploration in Giyani area, South Africa. Journal of Geochemical Exploration. doi:10.1016/j.gexplo.2014.11.018

Salminen, R., Batista, M., Bidovec, M., Demetriades, A., De Vivo, B., De Vos, W., Duris, M., Gilucis, A., Gregorauskiene, V., Halamic, J., Heitzmann, P., Lima, A., Jordan, G., Klaver, G., Klein, P., Lis, J., Locutura, J., Marsina, K., Mazreku, A., O’Connor, P., Olson, S., Ottesen, R., Petersell, V., Plant, J., Reeder, S., Salpeteur, I., Sandström, H., Siewers, U., Steenfelt, A., Tarvainen, T., 2005. Geochemical Atlas of Europe: Background information, methodology and maps (FOREGS). Geological Survey of Finland, Espoo.

Salminen, R., Tarvainen, T., Demetriades, A., Duris, M., Fordyce, F.M., Gregorauskiene, V., Kahelin, H., Kivisilla, J., Klaver, G., Klein, H., Larson, J.O., Lis, J., Locutura, J., Marsina, K., Mjartanova, H., Mouvet, C., O’Connor, P., Odor, L., Ottonello, G., Paukola, T., Plant, J.A., Reimann, C., Schermann, O., Siewers, U., Steenfelt, A., Van, der Sluys, J., de Vivo, B., Williams, L., 1998. FOREGS Geochemical Mapping Field Manual, Geological Survey of Finland: Guide, 47.

Sandström, H., Reeder, S., Bartha, A., Birke, M., Berge, F., Davidsen, B., Grimstvedt, A., HagelBrunnström, M.-L., Kantor, W., Kallio, E., Klaver, G., Lucivjansky, P., Mackovych, D., Mjartanova, H., van Os, B., Paslawski, P., Popiolek, E., Siewers, U., Varga-Barna, Z., van Vilsteren, E., Ødegard, M., 2005. Sample preparation and analysis, in: Salminen, R., Batista, 
M.J., Bidovec, M., Demetriades, A., De Vivo, B., De Vos, W., Duris, M., Gilucis, A., Gregorauskiene, V., Halamic, J., Heitzmann, P., Lima, A., Jordan, G., Klaver, G., Klein, P., Lis, J., Locutura, J., Marsina, K., Mazreku, A., O’Connor, P.J., Olsson, S.A., Ottesen, R.T., Petersell, V., Plant, J.A., Reeder, S., Salpeteur, I., Sandström, H., Siewers, U., Steenfelt, A., Tarvainen, T. (Eds.), FOREGS Geochemical Atlas of Europe, Part 1: Background Information, Methodology and Maps. Geological Survey of Finland, Otamedia Oy, Espoo, pp. $32-46$.

Shiller, A.M., 2010. Dissolved rare earth elements in a seasonally snow-covered, alpine/subalpine watershed, Loch Vale, Colorado. Geochimica et Cosmochimica Acta 74, 2040-2052.

Sholkovitz, E.R., 1995. The aquatic chemistry of rare earth elements in rivers and estuaries. Aquatic Geochemistry 1, 1-34. doi:doi:10.1007/BF01025229

Steinmann, M., Stille, P., 2008. Controls on transport and fractionation of the rare earth elements in stream water of a mixed basaltic-granitic catchment (Massif Central, France). Chemical Geology 254, 1-18.

Stolpe, B., Guo, L., Shiller, A.M., 2013. Binding and transport of rare earth elements by organic and iron-rich nanocolloids in Alaskan rivers, as revealed by field-flow fractionation and ICP-MS. Geochimica et Cosmochimica Acta 446-462. doi:http://dx.doi.org/10.1016/j.gca.2012.12.033

Tang, J., Johannesson, K.H., 2003. Speciation of rare earth elements in natural terrestrial waters: Assessing the role of dissolved organic matter from the modeling approach. Geochimica et Cosmochimica Acta 67, 2321-2339. doi:doi:10.1016/S0016-7037(02)01413-8

Tepe, N., Romero, M., Bau, M., 2014. High-technology metals as emerging contaminants: Strong increase of anthropogenic gadolinium levels in tap water of Berlin, Germany, from 2009 to 2012. Applied Geochemistry 45, 191-197.

Turekian, K.K. and Wedepohl, K.H., 1961. Distribution of the Elements in Some Major Units of the Earth's Crust. Geological Society of America Bulletin 72, 175-192.

Valla, P.G., Shuster, D.L., van der Beek, P.A., 2011. Significant increase in relief of the European Alps during mid-Pleistocene glaciations. Nature geoscience 4, 688-692.

Vissers, R.L.M., Meijer, P.T., 2012. Iberian plate kinematics and Alpine collision in the Pyrenees. Earth-Science Reviews 114, 61-83.

Wackernagel, H., 2003. Multivariate geostatistics. Springer.

Wolock, D.M., Hornberger, G.M., Beven, K.J., Campbell, W.G., 1989. The relationship of catchment topography and soil hydraulic characteristics to lake alkalinity in the northeastern United States. Water Resources Research 25, 829-837.

Wolock, D.M., Hornberger, G.M., Musgrove, T.J., 1990. Topographic effects on flow path and surface water chemistry of the Llyn Brianne catchments in Wales. Journal of Hydrology 115, 243259. 
673 Figure and table captions

674 Fig. 1 Simplified maps of (a) elevation and (b) geological units.|

675

676 Fig. 2 Principal component analysis: circle of correlations.

677

678 Fig. 3 First regionalized factor at short (structure 1) and at long range (structure 2).

679

680 Fig. 4 Cokrigged maps of (a) La, (b) Eu, and (c) Lu.

681

682

Fig. 5 Cokrigged maps of physicochemical properties (a) $\mathrm{Fe}$, (b) $\mathrm{HCO}_{3}{ }^{-}$, (c) $\mathrm{Mn}$, (d) organic 683 carbon, and (e) $\mathrm{pH}$.

684

685

Fig. 6 Upper continental crust(UCC)-normalized REE patterns in samples from (a) Dordogne

686 river and (b) Garonne river (UCC values are from McLennan 2001).

687

688

689

Fig. 7 Concentrations of $\mathrm{Nd}$ in river samples as a function of $\mathrm{pH}$ (Garonne-Dordogne

690

691

Fig. 8 Cerium anomaly as a function of distance to outlet (Garonne-Dordogne watershed).

692

693

Table 1 Descriptive statistics of selected REE and physicochemical properties.

694

695

Table 2 Principal component analysis: obtained components.

696

697

Table 3 Structural correlation coefficients.

698

699

Table 4 Correlation between factors and original variables. 
Table 1 Descriptive statistics of selected REE and physicochemical properties (to be continued).

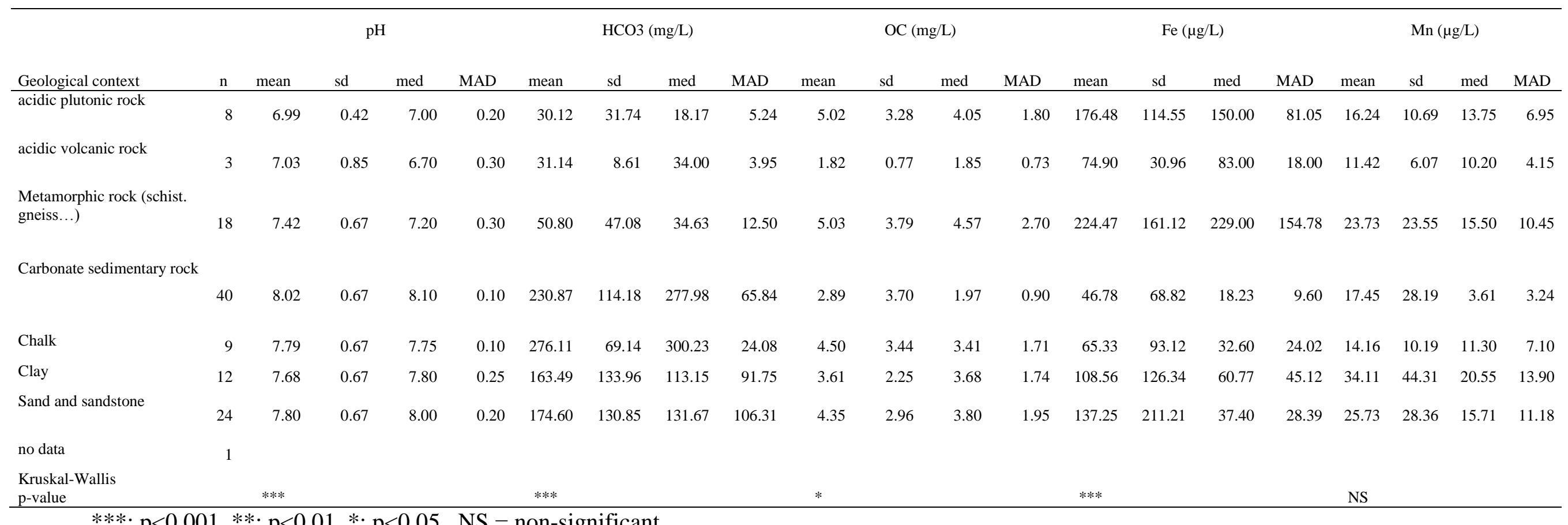

$* * *: \mathrm{p}<0.001, * *: \mathrm{p}<0.01, *: \mathrm{p}<0.05, \mathrm{NS}=$ non-significant. 
Table 1 Descriptive statistics of selected REE and physicochemical properties (continued).

\begin{tabular}{|c|c|c|c|c|c|c|c|c|c|c|c|c|c|}
\hline \multirow[b]{2}{*}{ Geological context } & \multirow[b]{2}{*}{$\mathrm{n}$} & \multicolumn{4}{|c|}{$\mathrm{La}(\mu \mathrm{g} / \mathrm{L})$} & \multicolumn{4}{|c|}{$\mathrm{Eu}(\mu \mathrm{g} / \mathrm{L})$} & \multicolumn{4}{|c|}{$\mathrm{Lu}(\mu \mathrm{g} / \mathrm{L})$} \\
\hline & & mean & $\mathrm{sd}$ & med & MAD & mean & $\mathrm{sd}$ & med & MAD & mean & $\mathrm{sd}$ & med & MAD \\
\hline acidic plutonic rock & 8 & 0.1491 & 0.0905 & 0.1490 & 0.0680 & 0.0083 & 0.0036 & 0.0070 & 0.0020 & 0.0031 & 0.0014 & 0.0030 & 0.0010 \\
\hline acidic volcanic rock & 3 & 0.0717 & 0.0071 & 0.0730 & 0.0050 & 0.0040 & 0.0010 & 0.0040 & 0.0010 & 0.0013 & 0.0006 & 0.0010 & $<0.001$ \\
\hline $\begin{array}{l}\text { Metamorphic rock (schist. } \\
\text { gneiss...) }\end{array}$ & 18 & 0.1374 & 0.1076 & 0.1250 & 0.0930 & 0.0095 & 0.0057 & 0.0080 & 0.0040 & 0.0031 & 0.0019 & 0.0030 & 0.0020 \\
\hline Carbonate sedimentary rock & 40 & 0.0280 & 0.0441 & 0.0170 & 0.0130 & 0.0055 & 0.0043 & 0.0050 & 0.0030 & 0.0013 & 0.0009 & 0.0010 & $<0.001$ \\
\hline Chalk & 9 & 0.0720 & 0.1333 & 0.0190 & 0.0090 & 0.0049 & 0.0069 & 0.0020 & 0.0010 & 0.0018 & 0.0016 & 0.0010 & $<0.001$ \\
\hline Clay & 12 & 0.0850 & 0.1267 & 0.0380 & 0.0240 & 0.0080 & 0.0087 & 0.0050 & 0.0030 & 0.0020 & 0.0018 & 0.0010 & $<0.001$ \\
\hline Sand and sandstone & 24 & 0.0941 & 0.1278 & 0.0340 & 0.0260 & 0.0080 & 0.0078 & 0.0050 & 0.0030 & 0.0025 & 0.0026 & 0.0010 & $<0.001$ \\
\hline no data & 1 & & & & & & & & & & & & \\
\hline $\begin{array}{l}\text { Kruskal-Wallis } \\
\text { p-value }\end{array}$ & & $* * *$ & & & & $*$ & & & & $* * *$ & & & \\
\hline
\end{tabular}

$* * *: \mathrm{p}<0.001, * *: \mathrm{p}<0.01, *: \mathrm{p}<0.05, \mathrm{NS}=$ non-significant. 
Click here to download Table: Table 2 armand jge.docx

Table 2 Principal component analysis: obtained components.

\begin{tabular}{cccc}
\hline Component & Eigenvalue & Variance (\%) & Cumulative variance \\
\hline F1 & 22.66 & 84.5 & 84.5 \\
F2 & 1.62 & 6.1 & 90.6 \\
\hline
\end{tabular}


Table 3 Structural correlation coefficients

\begin{tabular}{|c|c|c|c|c|c|c|c|c|}
\hline \multicolumn{9}{|c|}{ Short range $\mathrm{h}=120 \mathrm{~km}$} \\
\hline & $\mathrm{Eu}$ & $\mathrm{Fe}$ & $\mathrm{HCO}_{3}$ & $\mathrm{La}$ & $\mathrm{Lu}$ & $\mathrm{Mn}$ & $\mathrm{OC}$ & $\mathrm{pH}$ \\
\hline $\mathrm{Eu}$ & 1.000 & & & & & & & \\
\hline $\mathrm{Fe}$ & 0.640 & 1.000 & & & & & & \\
\hline $\mathrm{HCO}_{3}$ & -0.174 & -0.227 & 1.000 & & & & & \\
\hline $\mathrm{La}$ & 0.772 & 0.525 & -0.474 & 1.000 & & & & \\
\hline $\mathrm{Lu}$ & 0.682 & 0.444 & -0.409 & 0.568 & 1.000 & & & \\
\hline $\mathrm{Mn}$ & 0.644 & 0.856 & -0.156 & 0.533 & 0.315 & 1.000 & & \\
\hline $\mathrm{OC}$ & 0.735 & 0.409 & 0.000 & 0.251 & 0.364 & 0.400 & 1.000 & \\
\hline $\mathrm{pH}$ & -0.261 & -0.181 & 0.403 & -0.191 & -0.331 & -0.191 & 0.000 & 1.000 \\
\hline \multicolumn{9}{|c|}{ Long range $\mathrm{h}=250 \mathrm{~km}$} \\
\hline & $\mathrm{Eu}$ & $\mathrm{Fe}$ & $\mathrm{HCO}_{3}$ & $\mathrm{La}$ & $\mathrm{Lu}$ & $\mathrm{Mn}$ & $\mathrm{OC}$ & $\mathrm{pH}$ \\
\hline $\mathrm{Eu}$ & 1.000 & & & & & & & \\
\hline $\mathrm{Fe}$ & 0.879 & 1.000 & & & & & & \\
\hline $\mathrm{HCO}_{3}$ & -0.987 & -0.845 & 1.000 & & & & & \\
\hline $\mathrm{La}$ & 0.734 & 0.958 & -0.718 & 1.000 & & & & \\
\hline $\mathrm{Lu}$ & 0.865 & 0.995 & -0.823 & 0.957 & 1.000 & & & \\
\hline $\mathrm{Mn}$ & 0.109 & 0.561 & -0.087 & 0.752 & 0.572 & 1.000 & & \\
\hline $\mathrm{OC}$ & 0.428 & 0.796 & -0.355 & 0.858 & 0.802 & 0.873 & 1.000 & \\
\hline $\mathrm{pH}$ & -0.739 & -0.922 & 0.750 & -0.981 & -0.920 & -0.705 & -0.752 & 1.000 \\
\hline
\end{tabular}


Table 4 Correlation between factors and original variables.

\begin{tabular}{|c|c|c|}
\hline \multicolumn{3}{|l|}{ Short range $h=120 \mathrm{~km}$} \\
\hline & Factor 1 & Factor 2 \\
\hline $\mathrm{Eu}$ & 0.773 & 0.146 \\
\hline $\mathrm{Fe}$ & 0.493 & 0.106 \\
\hline $\mathrm{HCO}_{3}$ & -0.256 & 0.437 \\
\hline $\mathrm{La}$ & 0.441 & -0.044 \\
\hline $\mathrm{Lu}$ & 0.519 & -0.148 \\
\hline $\mathrm{Mn}$ & 0.687 & 0.183 \\
\hline $\mathrm{OC}$ & 0.378 & 0.252 \\
\hline $\mathrm{pH}$ & -0.296 & 0.580 \\
\hline Explained variance (\%) & 50.0 & 20.2 \\
\hline \multicolumn{3}{|l|}{ Long range $h=250 \mathrm{~km}$} \\
\hline & Factor 1 & Factor 2 \\
\hline $\mathrm{Eu}$ & -0.436 & 0.294 \\
\hline $\mathrm{Fe}$ & 0.796 & -0.074 \\
\hline $\mathrm{HCO}_{3}$ & -0.607 & 0.452 \\
\hline $\mathrm{La}$ & 0.814 & 0.104 \\
\hline $\mathrm{Lu}$ & 0.603 & -0.042 \\
\hline $\mathrm{Mn}$ & 0.374 & 0.423 \\
\hline $\mathrm{OC}$ & 0.639 & 0.393 \\
\hline $\mathrm{pH}$ & -0.648 & -0.029 \\
\hline Explained variance (\%) & 80.3 & 17.0 \\
\hline
\end{tabular}




\section{Figure 1}

Click here to download high resolution image

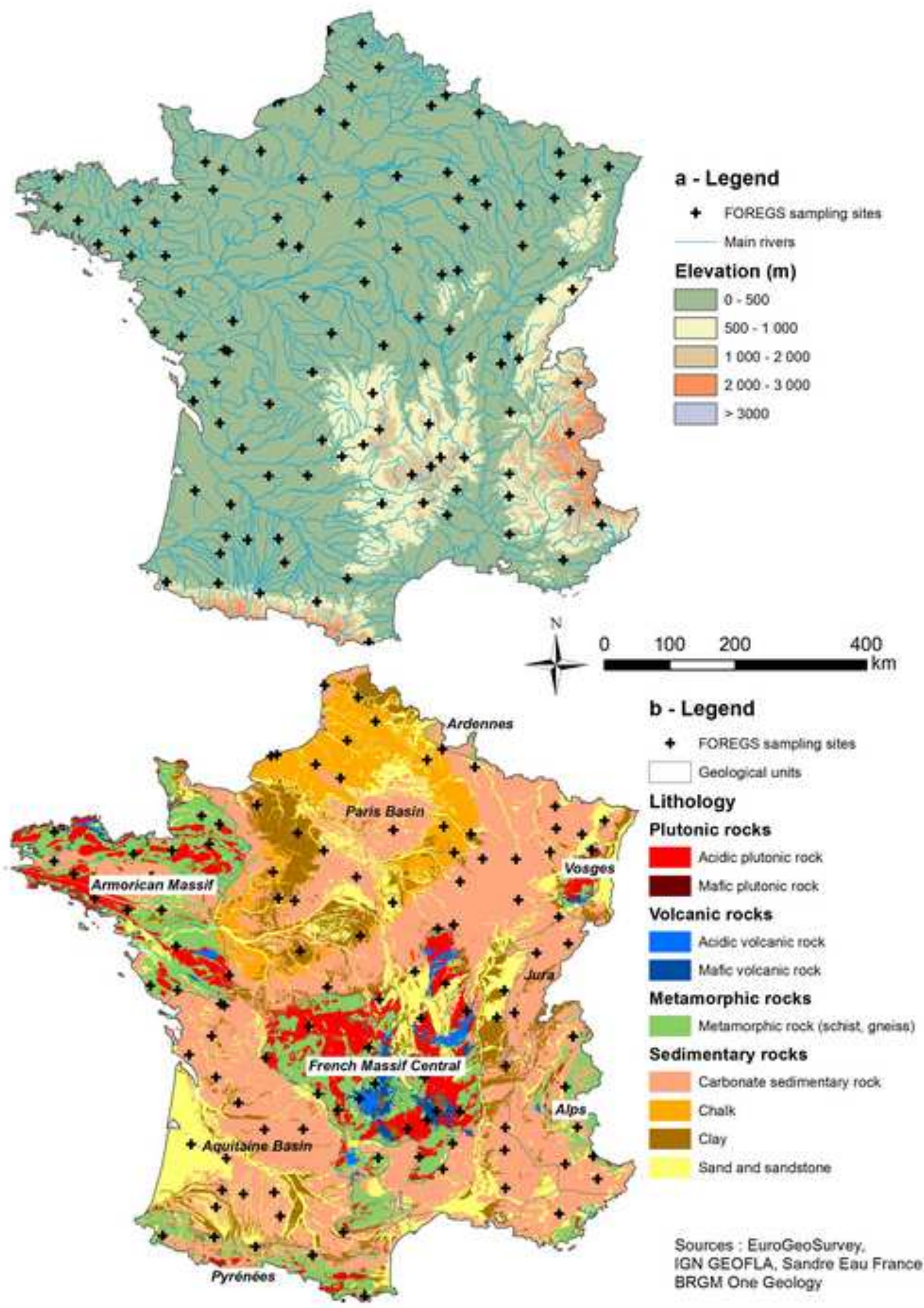

IGN GEOFLA, Sandre Eau France BRGM One Geology 
Figure 2

F2

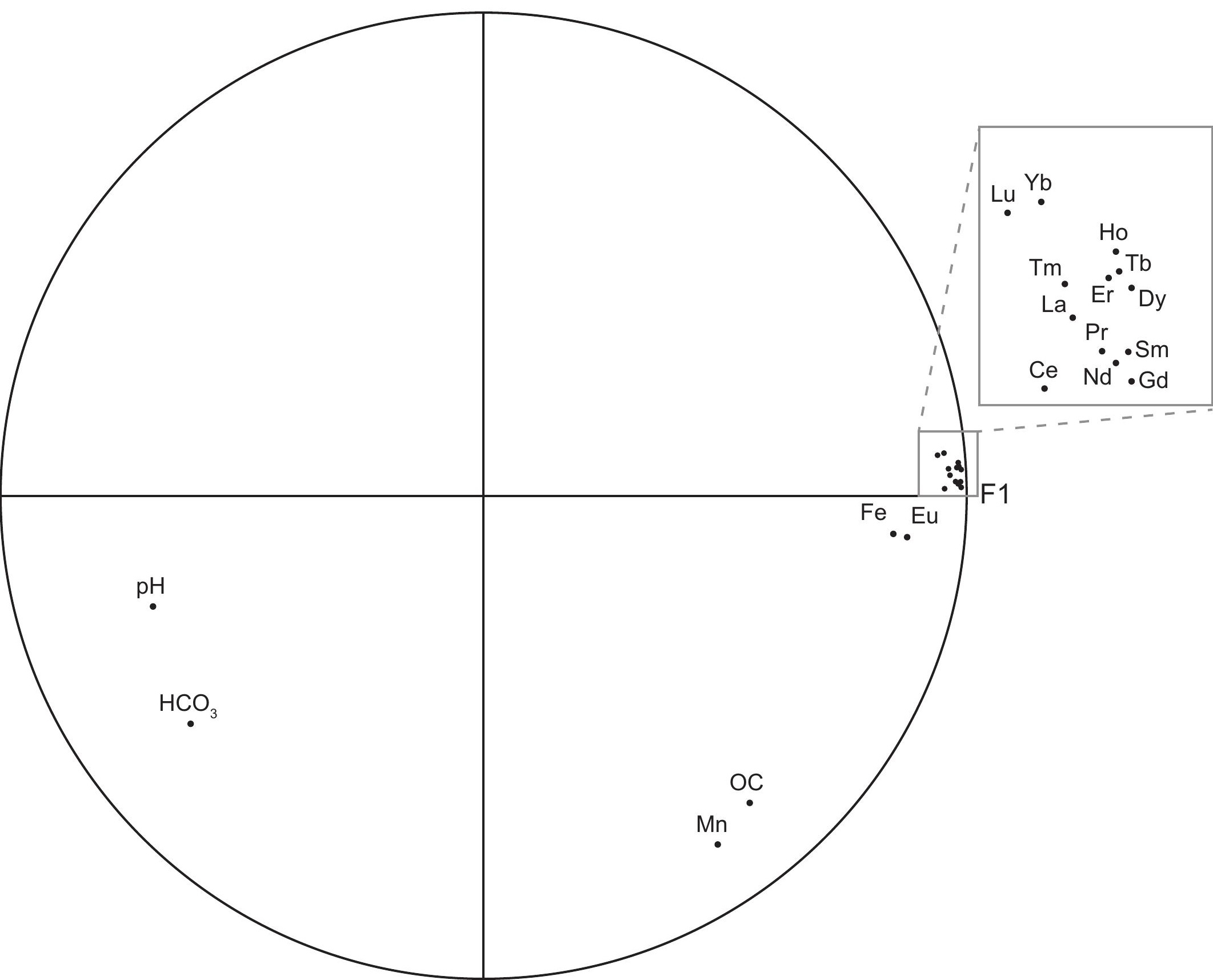



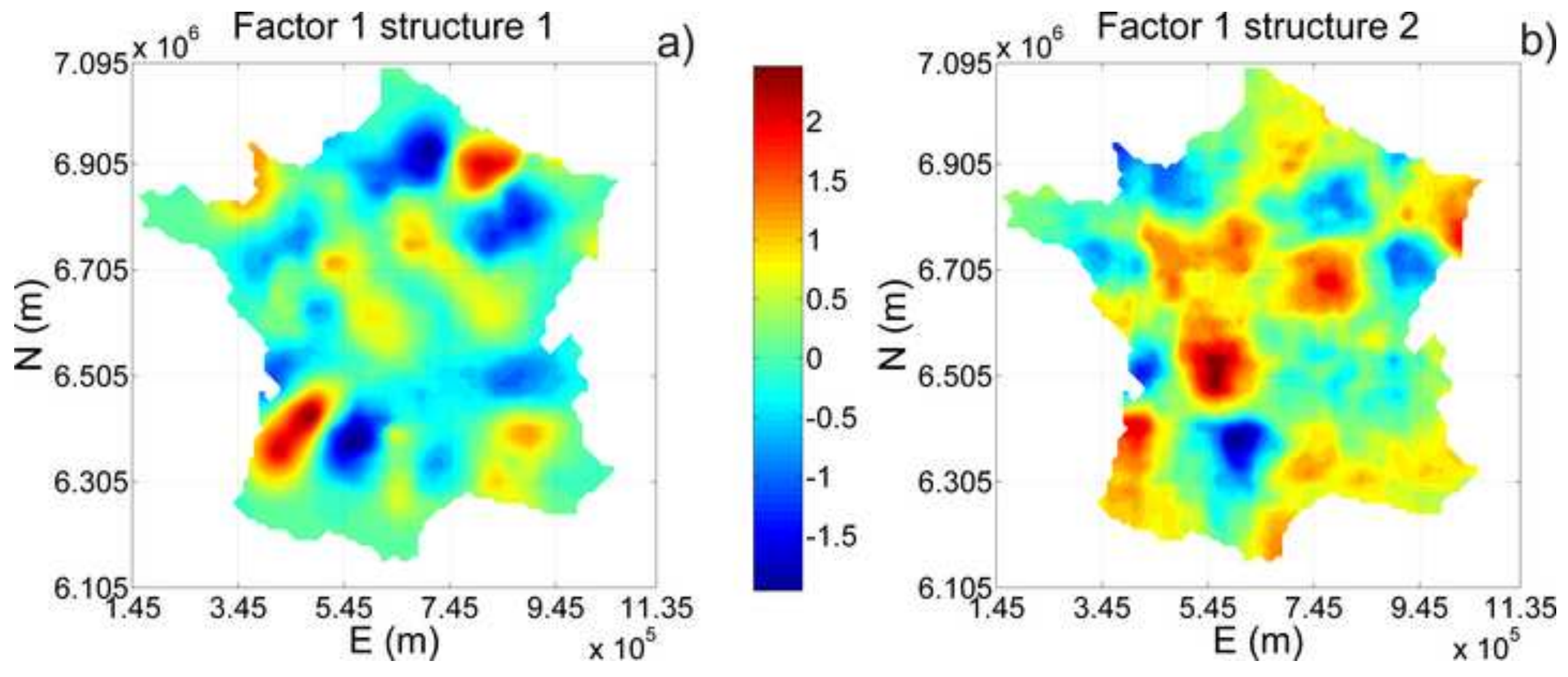

b) 
Click here to download high resolution image

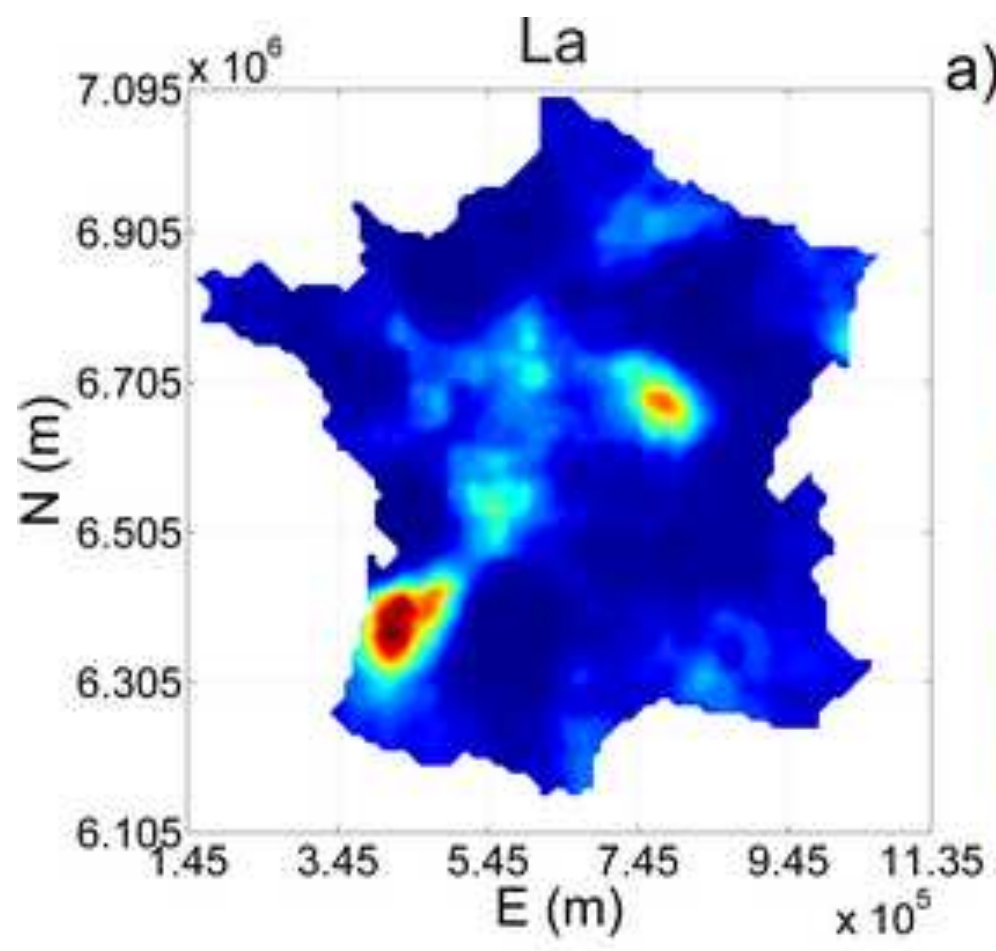

a) $(\mu \mathrm{g} / \mathrm{L})_{7.095} \times 10^{6} \quad \mathrm{Eu}$

b) $(\mu \mathrm{g} / \mathrm{L})$
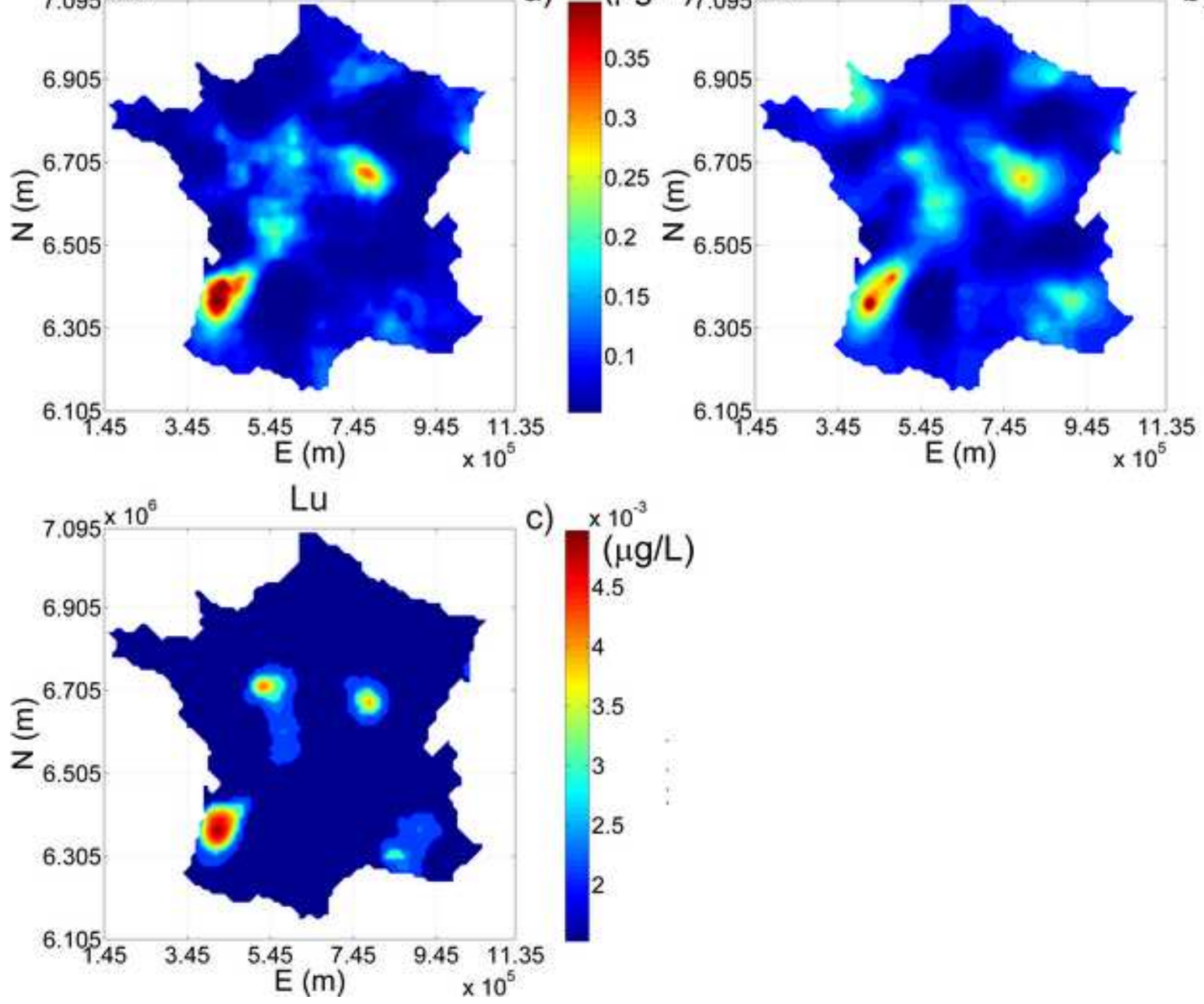
c)

e)
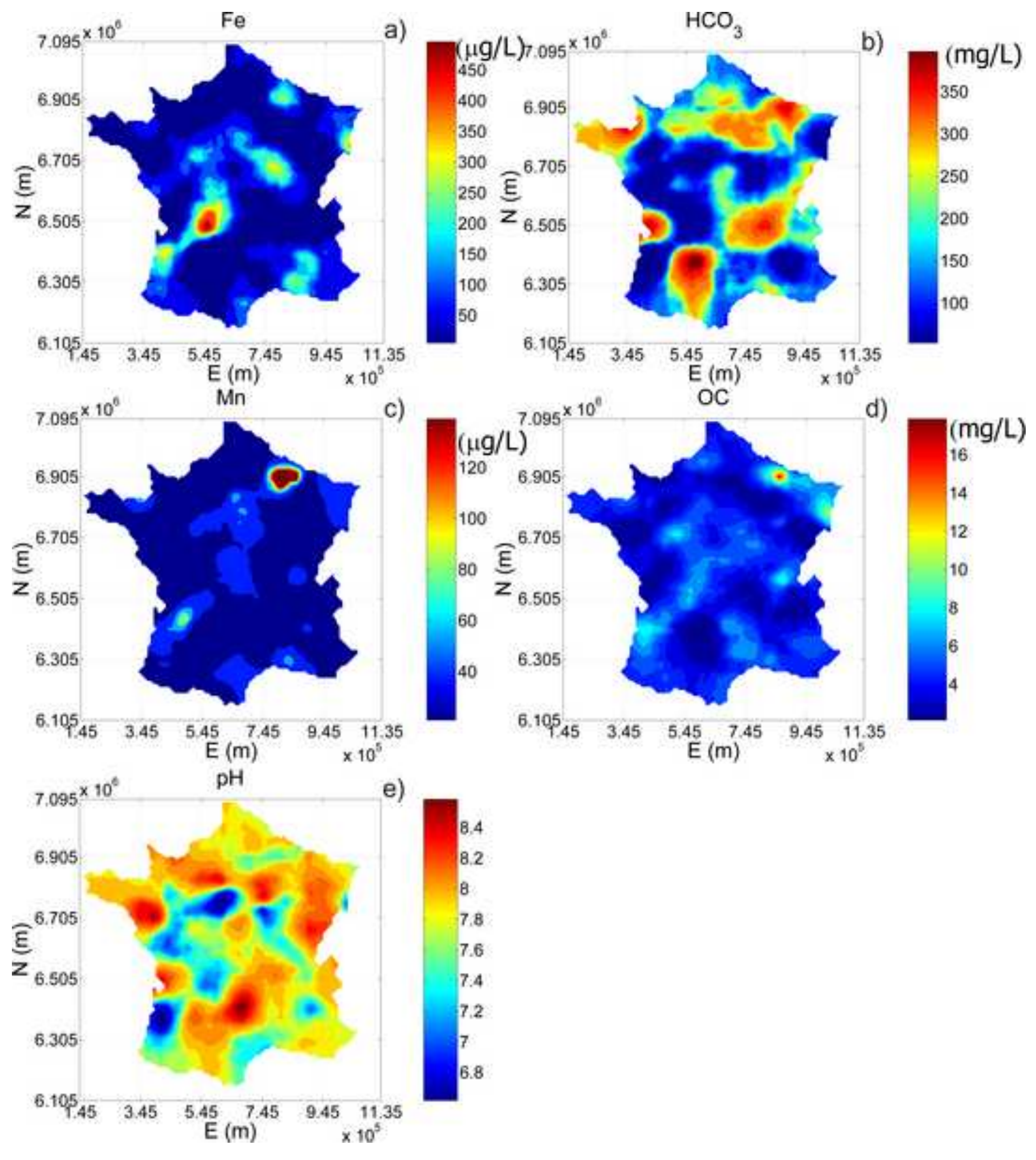

3.4

2

8

7.6

7.4

7.2 


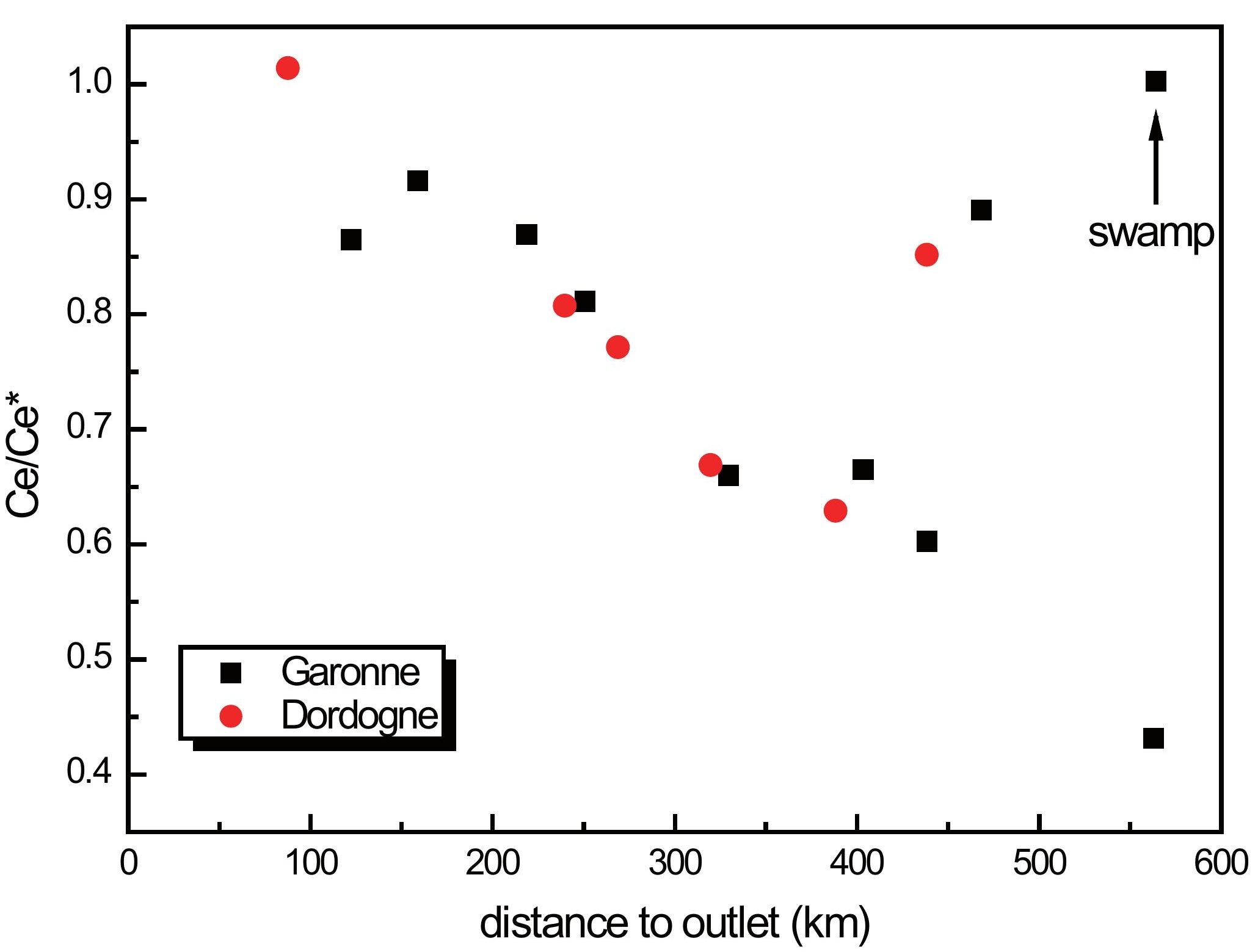

Figure 7 


\section{Authorship Confirmation}

Please save a copy of this file, complete and upload as the "Confirmation of Authorship" file.

As corresponding author I, Olivier Pourret, hereby confirm on behalf of all authors that:

1. This manuscript, or a large part of it, has not been published, was not, and is not being submitted to any other journal. If presented at a conference, the conference is identified. If published in conference proceedings, the publication is identified below and substantial justification for re-publication must be presented.

2. All text and graphics, except for those marked with sources, are original works of the authors, and all necessary permissions for publication were secured prior to submission of the manuscript.

3. All authors each made a significant contribution to the research reported and have read and approved the submitted manuscript.

Date _13/01/2015

\section{Previous conference presentation}

\section{Previous conference proceedings publication}

